Original Research

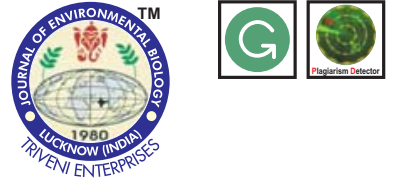

DOI : http://doi.org/10.22438/jeb/38/4/MS-259

\title{
Impact of zero tillage agriculture on the avian fauna in Ludhiana, Punjab
}

Authors Info

J. Kaur', T.K. Kler ${ }^{1 *}$, J.S. Kang ${ }^{2}$ and M. Kumar ${ }^{1}$

'Department of Zoology, Punjab Agricultural University, Ludhiana-141 004, India

${ }^{2}$ Department of Agronomy, Punjab Agricultural University, Ludhiana-141 004, India

*Corresponding Author Email : tejdeepkler@pau.edu

Key words

Avian fauna,

Biodiversity,

Direct seeded crop,

Paddy Crop,

Zero tillage

Publication Info

Paper received : 08.02.2016

Revised received : 17.06 .2016

Re-revised received : 14.09 .2016

Accepted:09.11.2016
Abstract

Aim: Birds are excellent indicators of the state of a healthy environment and form an integral component of agricultural ecosystem. Rapid agricultural intensification leads to uniform habitat system resulting in decline of farmland bird diversity throughout the world. Birds are intimately related to agricultural habitat for their needs such as food, shelter and breeding places. Keeping this in mind, it was planned to study the effect of zero tillage agriculture on avian diversity to generate baseline data.

Methodology: Bird observations were recorded in zero till wheat fields and direct seeded paddy fields of Punjab Agricultural University (latitude $30^{\circ} 54^{\prime} 147 \mathrm{~N}$ and longitude of $75^{\circ} 47^{\prime} 642 \mathrm{E}$ and $244 \mathrm{~m}$ above mean sea level), Ludhiana from May 2014 to April 2015. Line Transect Method was used for the survey of different bird species. Relative abundance (\%) was calculated as: (ni/N) $\times 100$, where $n i$ is the number of birds of ith species and $\mathrm{N}$ is the total number of birds of all species.

Results: Species recorded in zero till wheat and direct seeded paddy crop was 23 and 21 respectively. Seven omnivore and five grainivorous bird species were recorded as overlapping species in zero till and direct seeded paddy crops. Highest value of species richness was recorded at ripening stage of zero till wheat crop. Results of the present study indicated that zero till wheat and direct seeded paddy attracts more bird species as compared to intensively cultivated paddy.

Interpretation: In the direct seeded paddy crop, species richness was highest both at seedling stage and reproductive stage. In zero till, farming stubbles and chaff from the previous crop remained undisturbed on soil surface, and undisturbed soil provided spilled grains, weed seeds, insects and small mammals to birds to feed on, so greater number of species was evident. From the present study, it is summarized that species abundance and species diversity was more in zero tillage crop fields as compared to intensively cultivated fields, which signifies that zero till farming has potential for conservation of avian biodiversity in a more sustainable way, while allowing the farmers to continue cropping in intensively cultivated agro-climatic zones.

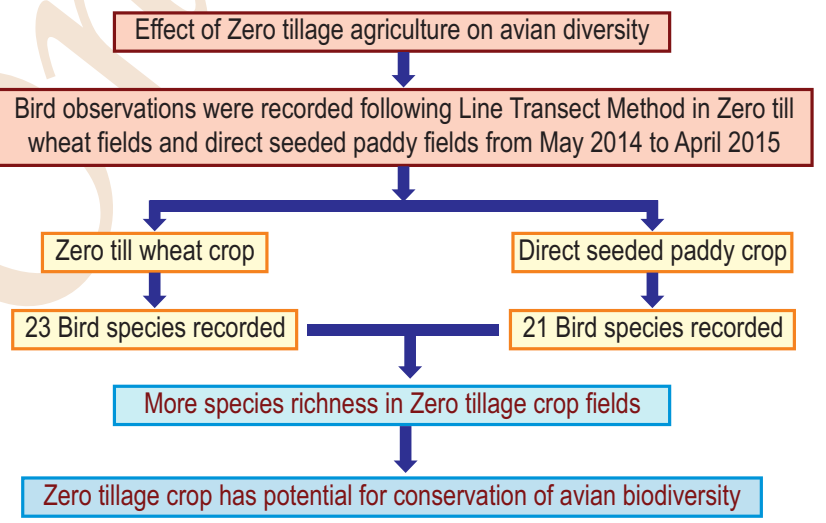




\section{Introduction}

The avifauna of India includes around 1263 species (Praveen et al., 2016), majority of bird species are associated with agro-ecosystem for their survival and make some impact on such systems (Ali, 2002; Kler and Kumar, 2015). Punjab has rich avian fauna comprising 240 species of birds (Toor et al., 1982). Cultural farming practices have major influence on the quality of wildlife habitat provided by croplands on the agricultural landscape (Best, 1985; Stefanova and Salek, 2013). Intensification of agriculture is considered to be responsible for decline of many bird species (Baillie et al., 1997; Washburn et al., 2016). So, it is important to consider how various tillage practices affect terrestrial wildlife such as birds in cropland situations (Lokemoen, 1997; Dyulgerova et al., 2015). Zero tillage is concept of conservational agriculture and it is a way of growing crops from year to year without disturbing the soil through tillage (Erenstein, 2009). Change in cropping pattern affects the feeding and nesting preferences of Barn Owl population in Central Valley of California (Kross et al., 2016). It is necessary to understand the importance of zero tillage cultivation to formulate bird conservation as well as management strategies. In view of the above, the present study was planned to determine the avian community structure in zero tillage crop fields of Punjab Agricultural University Ludhiana, Punjab, so as to generate data that would provide a baseline information for conservation of bird species.

\section{Materials and Methods}

The present study on avifauna was undertaken from May 2014 to April 2015 in zero tillage fields of wheat (PBW343; maturing duration 155 day; field area 1.5 hectare) and paddy (PR118; maturing duration 158 days, field area 1.5 hectare) located in Punjab Agricultural University, Ludhiana (latitude $30^{\circ}$ $54^{\prime} 147 \mathrm{~N}$ and longitude of $75^{\circ} 47^{\prime} 642 \mathrm{E}$ and $244 \mathrm{~m}$ above mean sea level). Line Transect Method was used for the survey of different bird species (Verner, 1985). Identification of birds was based on the keys described by Ali (2002). Total numbers of bird species and their abundance were estimated. Relative abundance (\%) was calculated as: (ni/N) $\times 100$, where ni is the number of birds of ith species and $\mathrm{N}$ is the total number of birds of all species. Species diversity $(\mathrm{H})$ was calculated by ShannonWiener index (Spellerberg and Fedor, 2003). Species diversity $(\mathrm{H})$ and Species evenness $(\mathrm{J})$ were calculated from bird abundance data (Krebs, 1985). Statistical method of Independent t-test was performed to find the difference between population of common bird species in zero till wheat and direct seeded paddy crops.

\section{Results and Discussion}

A total of 21 birds species were observed at different developmental stages of direct seeded paddy crop (Table 1). A total of sixteen birds were recorded at seedling stage; House crow, Asian pied starling and blue rock pigeon were the most represented in the bird population with $26.45 \%, 12.25 \%$ and $10.32 \%$ relative abundance, respectively (Table 1 ). House crow, common myna, cattle egret and red-wattled lapwing were noticed feeding on the insect and invertebrate prey. White-breasted kingfisher was solitary visitor and preyed on insects and small reptiles. It was observed that the collective relative abundance of three most abundant species namely House crow, Common myna and Black kite was recorded $52.16 \%$ at transplanting stage (Table 1). During the present study, House crow (21.42\%) was recorded as most abundant species followed by Cattle egret $(19 \%)$ and Black ibis (12\%) at tillering stage (Table 1). House Crow, Black Ibis and Cattle Egret walked in group in search of the prey. Asian Pied Starling was noticed to feed upon plant and insects. There were recorded 16 and 15 species at reproductive stage and ripening stage, respectively. Collective relative abundance of three most abundant species namely House Crow, Common Swallow and Black Kite was recorded $50.63 \%$ at reproductive stage (Table 1).

Mixed flocks of House crow and common swallow were noticed hovering over the direct seeded paddy fields to attack the insect species on direct seeded paddy crop. Black Drongo was mostly noticed feeding on the flying insects. Common Swallow $(27.11 \%)$ was recorded as the most abundant species followed by House Crow (18.22\%) and Blue Rock Pigeon (14.66\%) at ripening stage (Table 1). Grain ripening stage was inhabited by dominant group of omnivores of 6 species, followed by insectivores and grainivorous group of 4 species each. Small flocks of Blue Rock Pigeon and Ring Dove were noticed foraging on ripened grains which had fallen on the ground. Large flocks of Common Swallow were observed making aerial sallies over the ripened direct seeded paddy fields because of abundance of insect food on the direct seeded paddy crop. A total of 26 species of birds were observed during the present study (Table 6).

Shanon-Wiener index of bird diversity peaked at seedling stage of direct seeded paddy (2.36). The lowest species diversity was recorded at ripening stage (2.12) (Table 1). Evenness peaked at tillering stage of direct seeded paddy with highest value (0.91). The lowest species diversity was recorded at ripening stage (0.78) (Table 1).

At total of twenty three species were observed at different developmental stages of zero till wheat crop (Table 2). The data revealed that bird species richness at seedling stage was thirteen. House Crow (27.27\%) was recorded as most abundant species, followed by Blue Rock Pigeon (17.04\%), Common Swallow (10.22\%), Cattle Egret (9.09\%), Black Kite (7.95\%) and Rose-ringed Parakeet (6.81\%) (Table 2). Bird community comprised of sixteen species was recorded from the studied location at the tillering stage. House Crow was recorded as the most abundant bird species with relative abundance of $24.90 \%$, followed by Blue Rock Pigeon (16.34\%) and Rose-ringed 
Table 1: Bird community characteristics at different developmental stages in direct seeded paddy crop

\begin{tabular}{|c|c|c|c|c|c|}
\hline \multirow{2}{*}{$\begin{array}{l}\text { Crop stages } \rightarrow \\
\text { Bird species } \downarrow\end{array}$} & Seedling stage & Transplanting stage & Tillering stage & Reproductive stage & Ripening stage \\
\hline & \multicolumn{4}{|c|}{ Relative abundance $(\%)$} & \\
\hline House Crow & 26.45 & 17.39 & 21.42 & 22.36 & 18.22 \\
\hline Blue Rock Pigeon & 10.32 & _- & 5.71 & & 14.66 \\
\hline Black Kite & 4.51 & $\overline{13.04}$ & 9 & $\overline{13.15}$ & 12 \\
\hline Common Swallow & 7.09 & 4.00 & - & 15.13 & 27.11 \\
\hline Cattle Egret & 7.09 & 5.34 & $\overline{19}$ & 5.92 & 8 \\
\hline Rose-ringed Parakeet & 3.22 & 13.00 & 7.14 & 12.5 & 2.66 \\
\hline Common Myna & 8.38 & 21.73 & 7.14 & 3.94 & 6.22 \\
\hline Red-wattled Lapwing & 4.51 & 4.25 & 8.57 & 4.60 & 1.77 \\
\hline Black Drongo & 6.45 & _ & 2.85 & 2.63 & 1.33 \\
\hline Asian Pied Starling & 12.25 & $\overline{4} .49$ & 2.85 & 2.63 & 0.44 \\
\hline Ring Dove & 2.58 & 2.17 & _ & 2.63 & 2.22 \\
\hline Common Babbler & 0.64 & - & - & 4.60 & - \\
\hline Alexandrine Parakeet & 3.87 & - & $\overline{4} .28$ & & $\overline{0.88}$ \\
\hline Black lbis & - & - & 12 & $\overline{1.31}$ & 0.88 \\
\hline Ashy Prinia & $\overline{0} .64$ & - & - & 0.65 & - \\
\hline Jungle Babbler & - & $\overline{12.04}$ & - & 1.31 & $\overline{0.88}$ \\
\hline Common Hoopoe & $\overline{0} .64$ & - & - & - & - \\
\hline White-throated Munia & - & - & - & $\overline{1} .97$ & - \\
\hline Red-vented Bulbul & - & 2.17 & - & _- & - \\
\hline Plain Prinia & - & _ & - & 1.31 & $\overline{2} .66$ \\
\hline White-breasted Kingfisher & 1.29 & - & - & _ & _- \\
\hline Species Richness & 16 & $\overline{11}$ & $\overline{11}$ & $\overline{16}$ & $\overline{15}$ \\
\hline Species Diversity & 2.36 & 2.14 & 2.20 & 2.29 & 2.12 \\
\hline Species Evenness & 0.85 & 0.89 & 0.91 & 0.82 & 0.78 \\
\hline
\end{tabular}

Parakeet (11.28\%) (Table 2). Cattle Egret, House Crow, Redwattled Lapwing, Common Hoopoe, Bay-backed Shrike and Common Myna were noted feeding on the insects and soil invertebrates in zero till wheat fields. There were recorded 16 and 19 species at reproductive stage and ripening stage of zero till wheat crop. House Crow (17.85\%) was recorded as most abundant at reproductive stage followed by Blue Rock Pigeon $(15 \%)$ (Table 2). Common Swallow, Ashy Prinia, Common Hoopoe and Red-wattled Lapwing fed on plant, as well as ground insects. House Crow and Blue Rock Pigeon were recorded as abundant species at ripening stage of zero till wheat crop with relative abundance value of $21.43 \%$ and $15.70 \%$, respectively (Table 2). House Crow, Blue Rock Pigeon and Rose-ringed Parakeet fed on the ripened wheat grains from the standing crop or were removed from the earheads.

Shanon-Wiener index of bird diversity peaked at seedling stage of zero till wheat and the lowest species diversity was recorded at tillering stage. Evenness was highest at reproductive stage (Table 2).

Eighteen species were recorded as common in both zero till wheat and direct seeded paddy crops. No significant difference was found in the population of common bird species which were recorded in both zero till wheat and direct seeded paddy crops (Table 3). Zero till wheat and direct seeded paddy crops were dominated by seven common omnivore birds (Table 4). Rich diversity of omnivore indicates the abundance of plant food and animal food available in zero till wheat and direct seeded paddy fields. Five common insectivore bird species fed on diverse insect species at different developmental stages of zero till wheat and direct seeded paddy crops (Table 4). Paddy field Pipit and Baybacked Shrike were exclusive to direct seeded paddy crop, while Indian Robin and Plain Prinia were recorded feeding on the insects only in zero till wheat crop (Table 5). Five grainivorous species were found both in zero till wheat and direct seeded paddy crops (Table 4). It seems that zero till wheat and direct seeded paddy fields provided similar foraging opportunities to grainivorous birds. Black Kite was the common carnivore species in zero till wheat and direct seeded paddy. Great Grey Shrike and Indian Roller were found only in zero till wheat fields while Whitebreasted Kingfisher was noted in direct seeded paddy crop (Table 5). The presence of different bird species during different developmental stages of crop may be due to the simultaneous effect of field conditions, as well as crop stages.

Results of the present study indicated that zero till wheat and direct seeded paddy attracted more bird species as compared to intensively cultivated paddy. Kler and Singh (2007) reported nineteen bird species in intensively cultivated wheat fields of Punjab Agricultural University, Ludhiana. Kler (2010) observed fifteen bird species in intensively cultivated paddy fields 
Table 2: Bird community characteristics at different developmental stages of zero till wheat crop

\begin{tabular}{|c|c|c|c|c|}
\hline Crop stages $\rightarrow$ & Seedling stage & Tillering stage & Reproductive stage & Ripening stage \\
\hline Bird species $\downarrow$ & & Relative ab & & \\
\hline House Crow & 27.27 & 24.90 & 17.85 & 21.46 \\
\hline Blue Rock Pigeon & 17.04 & 16.34 & 15 & 15.70 \\
\hline Black Kite & 7.95 & 8.17 & 11.42 & 4.71 \\
\hline Common Swallow & 10.22 & 7.78 & 2.14 & 4.00 \\
\hline Cattle Egret & 9.09 & 8.56 & 7.14 & 3.15 \\
\hline Rose-ringed Parakeet & 6.81 & 11.28 & 14.28 & 9.42 \\
\hline Common Myna & 2.27 & 7.39 & 9.28 & 7.85 \\
\hline Red-wattled Lapwing & - & 5.83 & 7.14 & 5.28 \\
\hline Black Drongo & $\overline{2} .27$ & 2.72 & 2.85 & 5.23 \\
\hline Asian Pied Starling & 4.54 & 2.33 & 4.28 & 6.00 \\
\hline Ring Dove & 3.40 & 0.38 & 1.42 & 6.28 \\
\hline Common Babbler & - & 1.55 & 1.42 & 0.30 \\
\hline Alexandrine Parakeet & $\overline{4} .54$ & - & - & - \\
\hline Black Ibis & - & - & $\overline{1.42}$ & - \\
\hline Ashy Prinia & - & - & 2.14 & $\overline{2} .61$ \\
\hline Jungle Babbler & $\overline{3} .40$ & - & - & 1.00 \\
\hline Paddyfield Pipit & - & & & 3.66 \\
\hline Common Hoopoe & - & 0.77 & 0.71 & 0.52 \\
\hline White-throated Munia & - & - & 1.42 & 0.50 \\
\hline Bay-backed Shrike & $\overline{1.36}$ & $\overline{0} .38$ & - & - \\
\hline Great Grey shrike & - & 1.16 & - & - \\
\hline Indian Roller & - & 0.38 & - & - \\
\hline Indian Robin & $\begin{array}{l}- \\
-\end{array}$ & - & - & $\overline{1} .57$ \\
\hline Species Richness & $\overline{13}$ & $\overline{16}$ & $\overline{16}$ & 19 \\
\hline Species Diversity & 2.56 & 2.26 & 2.39 & 2.51 \\
\hline Species Evenness & 0.82 & 0.81 & 0.86 & 0.85 \\
\hline
\end{tabular}

Table 3 : Comparative statistical analyses of bird species observed both in zero till wheat and direct seeded paddy crops

\begin{tabular}{lll}
\hline Crops $\rightarrow$ & Wheat & Paddy \\
Bird species $\downarrow$ & & \\
\hline House Crow & $38.5 \pm 9.34$ & $27.8 \pm 6.86$ \\
Blue Rock Pigeon & $27.00 \pm 5.87$ & $14.6 \pm 5.89$ \\
Black Kite & $13.25 \pm 3.22$ & $13.2 \pm 4.20$ \\
Common Swallow & $10.25 \pm 3.54$ & $19.4 \pm 11.16$ \\
Cattle Egret & $11.75 \pm 3.47$ & $10.6 \pm 2.61$ \\
Rose-ringed Parakeet & $18.50 \pm 4.51$ & $6.20 \pm 0.73$ \\
Common Myna & $10.50 \pm 3.92$ & $9.40 \pm 1.91$ \\
Red-wattled Lapwing & $9.25 \pm 3.25$ & $5.20 \pm 0.96$ \\
BlackDrongo & $5.75 \pm 1.75$ & $3.80 \pm 1.68$ \\
Asian Pied Starling & $7.00 \pm 1.73$ & $5.60 \pm 3.38$ \\
Ring Dove & $4.50 \pm 2.53$ & $2.80 \pm 0.96$ \\
Common Babbler & $1.75 \pm 0.85$ & $1.40 \pm 1.16$ \\
Alexandrine Parakeet & $1.00 \pm 1.00$ & $2.20 \pm 1.11$ \\
Black Ibis & $0.50 \pm 0.50$ & $2.20 \pm 1.28$ \\
Ashy Prinia & $2.00 \pm 1.22$ & $0.20 \pm 0.2$ \\
Jungle Babbler & $1.00 \pm 0.70$ & $2.00 \pm 1.09$ \\
Common Hoopoe & $1.00 \pm 0.40$ & $0.20 \pm 0.2$ \\
White-throated Munia & $2.25 \pm 1.31$ & $0.60 \pm 0.6$ \\
\hline
\end{tabular}

*Significant difference of bird population at $p<0.05$ in wheat and paddy crops; values are mean of \pm SE 
Table 4 : Bird species recorded both in direct seeded paddy and zero till wheat crops

\begin{tabular}{llll}
\hline Insectivore & Granivore & Carnivore & Omnivore \\
\hline Common Swallow & Blue Rock Pigeon & Black Kite & House Crow \\
Red-wattled Lapwing & Rose-ringed Parakeet & - & Cattle Egret \\
BlackDrongo & Ring Dove & - & Common Myna \\
Common Hoopoe & Alexandrine Parakeet & - & Asian Pied Starling \\
Ashy Prinia & White-throated Munia & - & Common Babbler \\
- & - & - & Black Ibis \\
- & - & - & Jungle Babbler \\
\hline
\end{tabular}

Table 5: Bird species observed exclusively in zero till wheat and direct seeded paddy crops

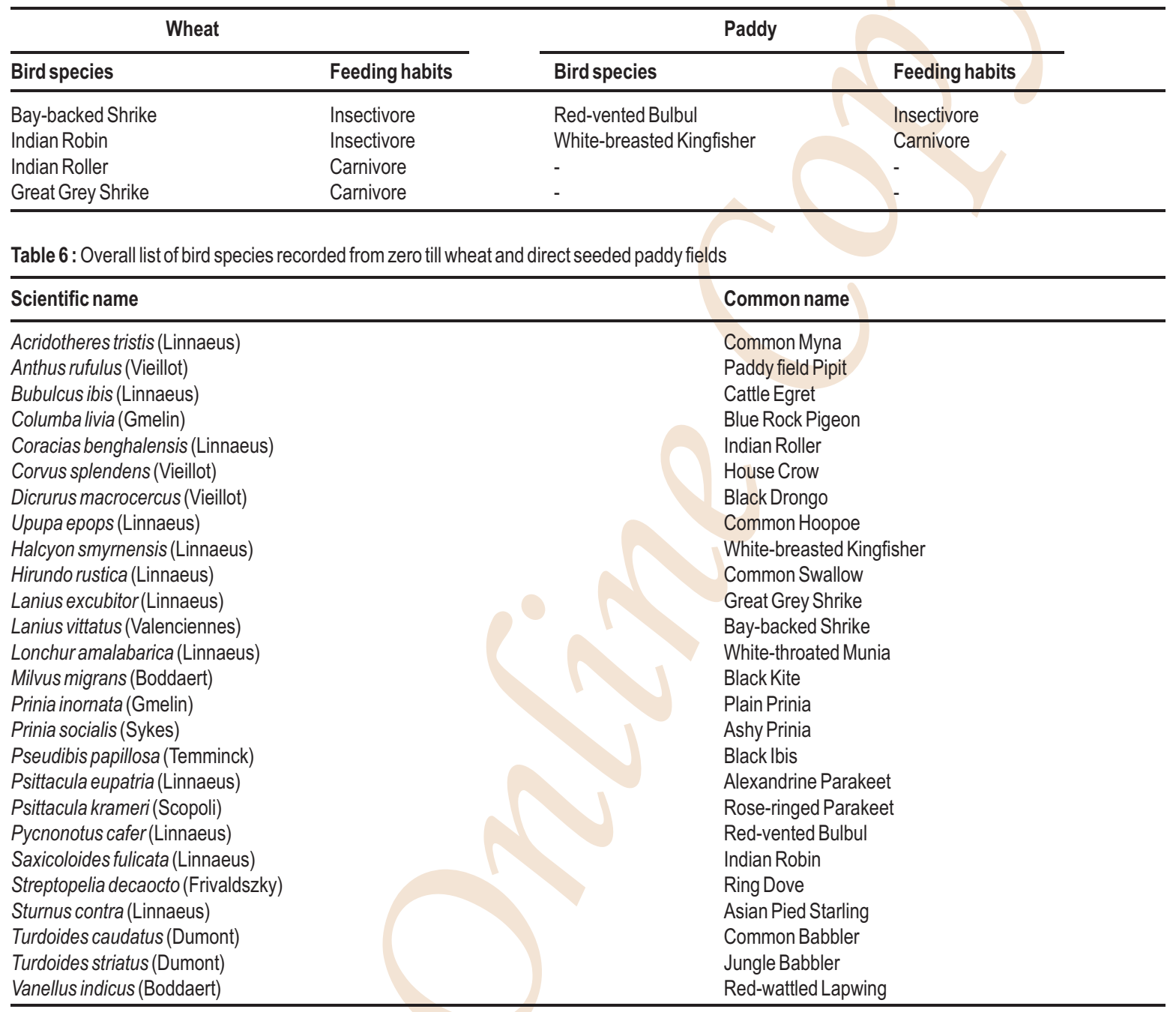

of Punjab Agricultural University. Urbanization, intensive agriculture, either crop production or pastoral-farming, have indirect negative effect on the bird population by reducing the quality and availability of food supplies and nesting sites (Rajashekara and Venkatesha, 2011, 2015; Verhulst et al., 2004).
In zero till farming, stubbles and chaff from the previous crop remained undisturbed on soil surface, and undisturbed soil provided spilled grains, weed seeds, insects and small mammals to birds to feed on, so greater number of species was evident. O'Connor and Shrubb (1986) had emphasized that a diverse 
community of species limited by food could exists only in habitat which could offer a diversity of foods. It was stated that ploughed fields may be preferred by many species as they hold readily accessible food resources (Wilson et al., 1996; Stefanova and Salek, 2013; Washburn et. al., 2016). In contrast, the loss of stubbles during winter, and a subsequent reduction in the availability of seed food is considered as an important factor in the decline of birds in croplands (Potts, 1997; Dyulgerova et. al., 2015). Ploughed fields are avoided, probably because they provided little seed or invertebrate food with birds preferring those where the stubbles remains even when seed densities were higher in ploughed compared to uncultivated fields (Hart et al., 2001). Some other workers have also reported that conservational agriculture is beneficial to birds while remaining economical to the farmers (Beecher, 2002; Dyulgerova et al., 2015).

In the present study, exceptionally large flocks of Common Swallow were seen exclusively in zero till plots. Field et al. (2007) recorded 14,000 Starlings exclusively on two conservation tillage plots. From the present study, number of insectivore species was recorded highest among all the species that were observed in zero till wheat and direct seeded paddy. Holland (2004) stated that the conservational tillage attracts many species in cropland habitat as it provides seed food in winter and higher level of organic matter; and the higher level of organic matter and weeds encourage arthropods in summer.

In intensive cultivation, arthropods that are important dietary items for birds are also susceptible to tillage practices, e.g., Coleoptera, Diptera, Hymenoptera, Arachnida, Annelida and Molluska (Wilson et al., 1999; Kross et al., 2016). In United Kingdom, the occurrence of granivore birds was higher in conservation tillage established fields than fields established by ploughing across a range of crop types (Cunningham et al., 2005). Kler (2008) found that the multi-layered crop vegetation at grain maturing stage of paddy had attracted birds belonging to both the insectivore and granivore groups.

From the present study, it is summarized that species abundance and species diversity was more in zero tillage crop fields as compared to intensively cultivated fields, which signifies that zero tillage cultivation method encourages bird population. It also revealed that zero till farming has potential to provide some of the benefits to birds while allowing farmers to continue cropping, thus suggesting that zero tillage cropping patron was more suitable for conservation of avian biodiversity in intensively cultivated agro-climatic zones of Punjab State.

\section{Acknowledgment}

Authors are grateful to the Head, Department of Zoology, Punjab Agricultural University, Ludhiana for providing necessary facilities.

\section{References}

Ali, S.: The Book of Indian Birds. $13^{\text {th }}$ Edn., Bombay Natural History Society: Oxford University Press (2002).

Baillie, S.R., R.D. Gregory and G.M. Siriwardena: Farmland bird declines: Patterns, processes and prospects. In: Symposium Proceeding No. 69 of British Crop Protection Council on Biodiversity and Conservation Agriculture, Farnham. pp. 65-68 (1997).

Beecher, N.A.: Agroecology of birds in organicand non-organic farmland. Conserv. Biol., 6, 1621-30 (2002).

Best, L.B.: Conservation vs Conventional tillage: wildlife management considerations. In: A system approach to conservation tillage (Ed.: T.M. D'Itri). Lewis Publishers, pp. 315-26 (1985).

Cunningham, H.M., R.B. Bradbury, K. Chaney and A. Wilcox: Effect of non-inversion tillage on field usage by UK farmland birds in winter. Bird Study, 52, 173-79 (2005).

Dyulgerova, S., M. Gramatikov, H. Pedashenko, K. Vassilev, V. Kati and S. C. Nikolove: Farmland birds and agricultural land abandonment: Evidences from Bulgaria. Acta. Zool. Bulg., 67, 223-234 (2015).

Erenstein, O.: Zero-tillage in the rice-wheat system of the Indo-Gangetic Plains: A review of impacts and sustainability implications. IFPRI. Discussion Paper 916 (2009).

Field, R.H., S. Benke, K. Badnoyi and R.B. Bradbury: Influence of conservation tillage on winter bird use of arable fields in Hungary. Agr. Ecosyst. Environ., 120, 399-404 (2007).

Hart, J.D.A., W.A. Murray, T. Milsom, D. Parrott, J. Allcock, J. Watola, D. Bishop, P.A. Robertson, J.M. Holland, S.E. Southway, M. Begbie and T. Birkett: The abundance of farmlands birds within arable fields in relation to seed density. Aspects Appl. Biol., 67, 221-28 (2001).

Holland, J.M.: The environmental consequences of adopting conservation tillage in Europe: Reviewing the evidence. Agr. Ecosyst. Environ., 103, 1-25 (2004).

Kler, T. K. and M. Kumar: Avian fauna recorded from the agricultural habitat of Punjab state. Agri. Res. J., 52, 83-90 (2015).

Kler, T.K. and S. Singh: Studies on the avian community in wheat field. Pestology, 31,44-47(2007).

Kler, T.K.: Occurrence of avian species in relation to vegetation in paddy fields. Pestology, 32, 51-55 (2008).

Kler, T.K.: Role of insectivorous bird species in rice ecosystem. Pestology, 34,47-50 (2010).

Krebs, C.J.: Ecology: The experimental analysis of distribution and abundance. $3^{\text {rd }}$ Edn., pp. 513-42 (1985).

Kross, S. M., R.P. Bourbour and B.L. Martinico: Agricultural land use, barn owl diet and vertebrate pest control implications. Agri. Eco. Envi., 223, 167-174 (2016)

Lokemoen, J.T. and J.A. Beisen: Bird use and nesting in conventional, minimum-tillage and organic croplands. J. Wildl. Manage., 61, 644-55 (1997).

O'Connor, R. J. and M. Shrubb: Farming and birds. Cambridge Univ. Press, Cambridge, U.K., p. 290 (1986).

Potts, G.R.: Cereal farming, pesticides and grey patridges. In: Farming and Birds in Europe (Eds.: D.J. Pain and M.W. Pienkowski). Academic Press, London, pp. 157-77 (1997).

Praveen, J., R. Jayapal and A. Pittie: A checklist of birds of India. Indian Bird, 11, 113-172 (2016).

Rajashekara, S. and M.G. Venkatesha: Community composition of 
aquatic birds in lakes of Bangalore, India. J. Env. Bio., 32, 77-83 (2011).

Rajashekara, S. and M.G. Venkatesha: Temporal and spatial avian community composition in urban landscapes of the Bangaluru region, India. J. Env. Bio., 36, 607-616 (2015).

Spellerberg, I.F. and P.J. Fedor: A tribute to Claude Shannnon (19162001) and a plea for more rigorous use of species richness, species diversity and the "Shannon-Wiener" Index. Glob. Ecol. Biogeo., 12, 177-79 (2003).

Stefanova, M. and M. Salek: Integrated farming methods and their impact on herb and bird communities of agricultural land - A review. J. Cent. Euro. Agri., 14, 305-317 (2013).

Toor, H.S., A.K. Chakravarthy, M.S. Dhindsa, P.S. Sandhu and P.K. Rao: A checklist of birds of Punjab and Chandigarh. Punjab Agricultural University, Ludhiana, India (1982).
Verhulst, J., A. Baldi and D. Kleijin: Relationships between land-use intensity and species richness and abundance of birds in Hungary. Agr. Ecosyst. Environ., 104, 465-73 (2004).

Verner, J.: Assessment of counting techniques. Curr. Ornithol., 2, 247302 (1985).

Washburn, B.E., R.M. Swearingin, C.K. Pullins and M.E. Rice: Composition and diversity of avian communities using a new urban habitat: Green Roofs. Env. Mgmt., 57, 1230-1239 (2016).

Wilson, J.D., A.J. Arroyo, S.C. Clark and R.B. Bradbury: A review of the abundance and diversity of invertebrate and plant foods for granivorous birds in northern Europe in relation to agriculture change. Agr. Ecosyst. Environ., 75, 13-30 (1999).

Wilson, J.D., R. Taylor and L.B. Muirhead: Field use by farmland birds in winter: An analysis of field type preferences using resampling methods. Bird Study, 43, 320-332 (1996). 